\title{
The Effect of Perforated Tipping Paper on the Yield of Various Smoke Components *
}

\author{
by V. Norman \\ Research Department, Liggett and Myers Incorporated, Durham, N.C., U.S.A.
}

\section{INTRODUCTION}

There have been numerous publications dealing with ventilation through porous cigarette paper during the smoking of a cigarette $(3,4,6,7,9,10,11,14,17)$.

The current presentation is not concerned with cigarette paper but deals with the effect that perforations in the tipping have on the composition of smoke. The idea of tipping perforation is rather old and there is a British patent issued in the neighborhood of 1890 that covers this principle. Nevertheless, there have been very few publications that deal with the investigation of this system. Morie and Sloan (13) and Mikami, Naito and Kaburaki (12) have briefly reported the effect of filter perforations on carbon monoxide and carbon dioxide yields. Kiefer (5) and Roper (16) have compared the effect of filter perforations on the relative yields of carbon monoxide, nicotine-free-dry-smoke and nicotine.

A perforated filter is a somewhat simpler system than porous or perforated paper since, unlike cigarette paper which burns up during smoking, the tipping perforations stay intact throughout the life of the cigarette.

\section{EXPERIMENTAL AND APPARATUS}

The two ventilation systems used in the experiments are depicted in Figure 1.

One system consisted of an empty mouthpiece tube and an impervious peripheral insert positioned such that all

Figure 1. Two ventllation systems used in the study.

The arrows depict the principal gas flow patterns.
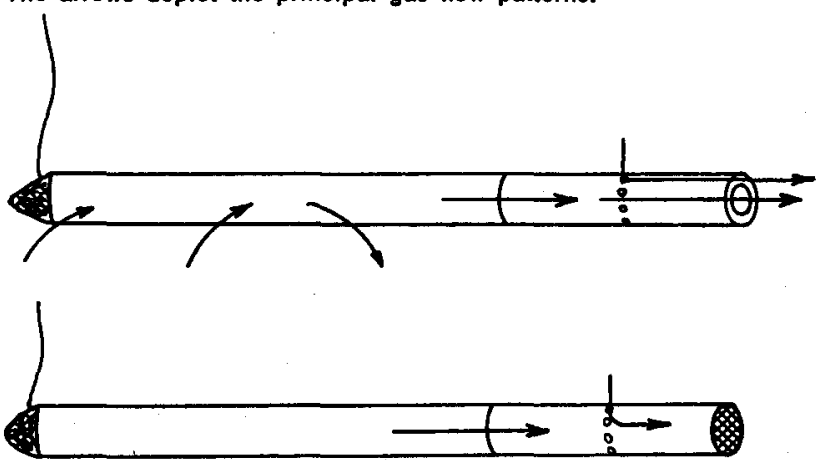

- Presented at the meeting of the CORESTA Smoke Study Group held in Nice, France, September 13-14, 1973.
Figure 2. Schematic representation of the device used to measure the degree of ventilation.

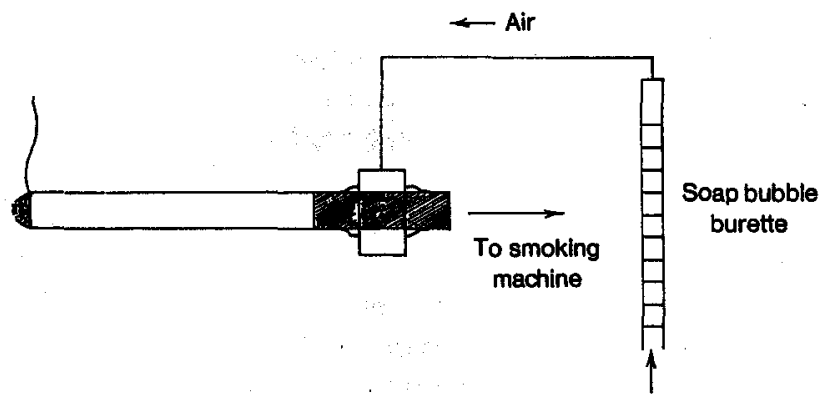

the diluting air stream enters through the periphery whereas the smoke stream comes in predominantly through the central passage. This system eliminates filtration complications and provides more information about what happens in the cigarette cone when the air flow through the cigarette is varied.

The second model was equipped with a cellulose acetate filter with the air stream entering directly into the filter tow. This system reflects the additional complicating influence of varying filtration efficiency which would be mainly due to different smoke volume flow rates through the filter.

In the test cigarettes the tobacco column, paper, filter, etc. were kept constant and only the draw resistance of the ventilating passages was varied by varying the number of perforations.

Figure 2 shows the device that was used to measure the degree of ventilation. Basically, the volume of air that was pulled into the cigarette through the perforations during smoking was measured directly with a bubble

Figure 3. A typical puff-by-puff course of ventllation volume during the smoking of a clgarette.

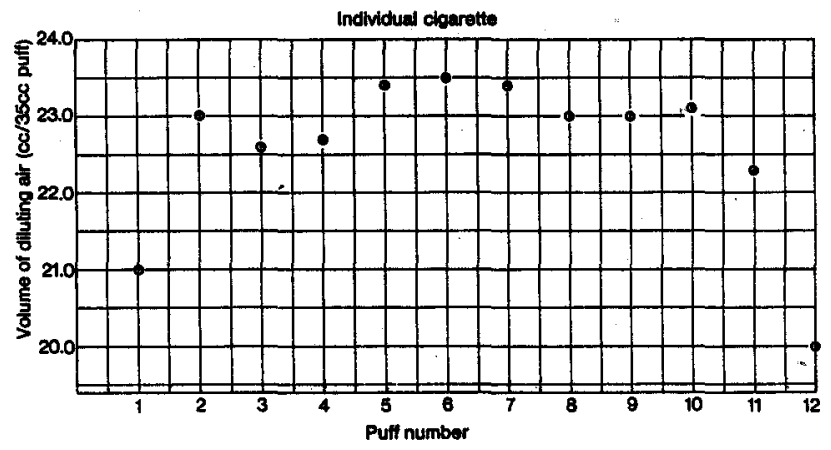


Figure 4. A schematic representation of the Important components of pressure drop.

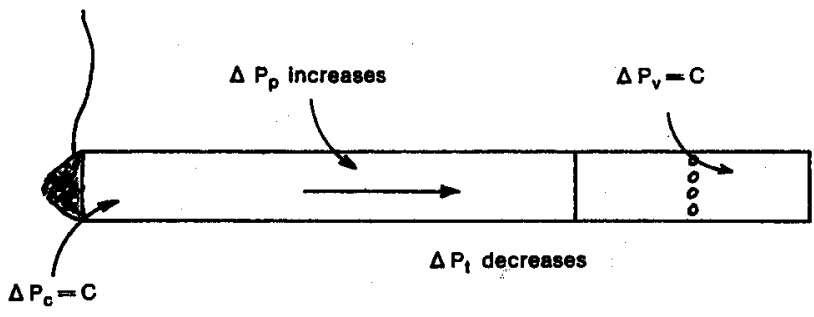

burette. The per puff ventilation volume was averaged over the life of the cigarette.

Figure 3 shows a typical puff by puff course of ventilation volume during the smoking of a cigarette.

Thus, even though the cigarette becomes successively shorter, the proportion of ventilating air does not change a great deal.

Figure 4 depicts the four components of pressure drop that are of significance in determining the air flow pattern through the cigarette.

First of all, the resistance of the perforations is constant. Since the air flow through perforations is also reasonably constant, the pressure drop of the perforations $\left(\Delta \mathrm{P}_{\mathrm{v}}\right)$ remains constant through the smoking of a cigarette. The cone resistance is also constant and its pressure drop $\left(\Delta \mathrm{P}_{\mathrm{c}}\right)$ probably remains nearly invariant.

As the length of the tobacco column decreases, its pressure drop $\left(\Delta P_{t}\right)$ decreases whereas the pressure drop of the paper envelope $\left(\Delta P_{p}\right)$ increases as the paper area decreases. The fact that the proportion of ventilating air does not change appreciably over the smoking of the cigarette implies that the changes in paper and tobacco column pressure drops approximately compensate for one another. This observation has been noted previously in the literature, e.g., by Meyer-Abich (9).

A series of cigarettes were smoked where the proportion of ventilating air varied from about $20 \%$ to about $70 \%$ of the puff volume and analyses were carried out for the components of smoke listed in Figure 5.

The compounds which were monitored fall roughly into five general categories of volatility [cf. classification by Waltz and Häusermann (18)]:

1. Substances that are gases at room temperature,

2. Substances that boil in the neighborhood of room temperature,

Flgure 5. Classlfication of the determined smoke componente.

$1-\mathrm{CO}, \mathrm{CO}_{2}$, NO

2- HCN, aldehydes, acetaldehyde, acrolein, acetone, isoprene

3 - Particulate $\mathrm{H}_{2} \mathrm{O}$

4 - Nicotine, volatile phenols, menthol

5- Waxes

Wet smoke (TPM)

Nicotine-free-dry-smoke (NFDS)
3. Water,

4. Substances that have low but significant vapor pressures at room temperature,

5. Relatively non-volatile materials still possessing sufficient vapor pressure at elevated temperatures to permit sublimation or distillation.

In addition the two mixtures of Wet Smoke Solids or Total Particulate Matter and Nicotine-Free-Dry-Smoke (NFDS) were investigated.

\section{DISCUSSION AND RESULTS}

In order to interpret as two why the yields of various smoke components are affected differently at different degrees of dilution one has to consider the origin of the compounds.

Thus, $\mathrm{CO}$ and $\mathrm{CO}_{2}$ originate in part from combustion and in part from decarboxylation of the substrate (carbohydrates, carboxylic acids, etc.). NO is strictly a decomposition product of the nitrate in tobacco leaf. $\mathrm{HCN}$ is principally a product of proteinic leaf constituents. Aldehydes arise mainly from carbohydrate precursors. Isoprene is mainly a product of various terpenoid compounds. Water arises in part as a combustion product, in part from dehydration of the substrate, and in part from distillation of tobacco moisture. Nicotine, and menthol are on tobacco to begin with and are sublimed or distilled into smoke. Phenol (and phenols) are degradation products of polyphenols, lignin and various other precursors.

The term "waxes" was used to denote non-polar highboiling substances - long-chain hydrocarbons and perhaps some esters. A part of those are native to

\section{Flgure 6. Carbon monoxide.}

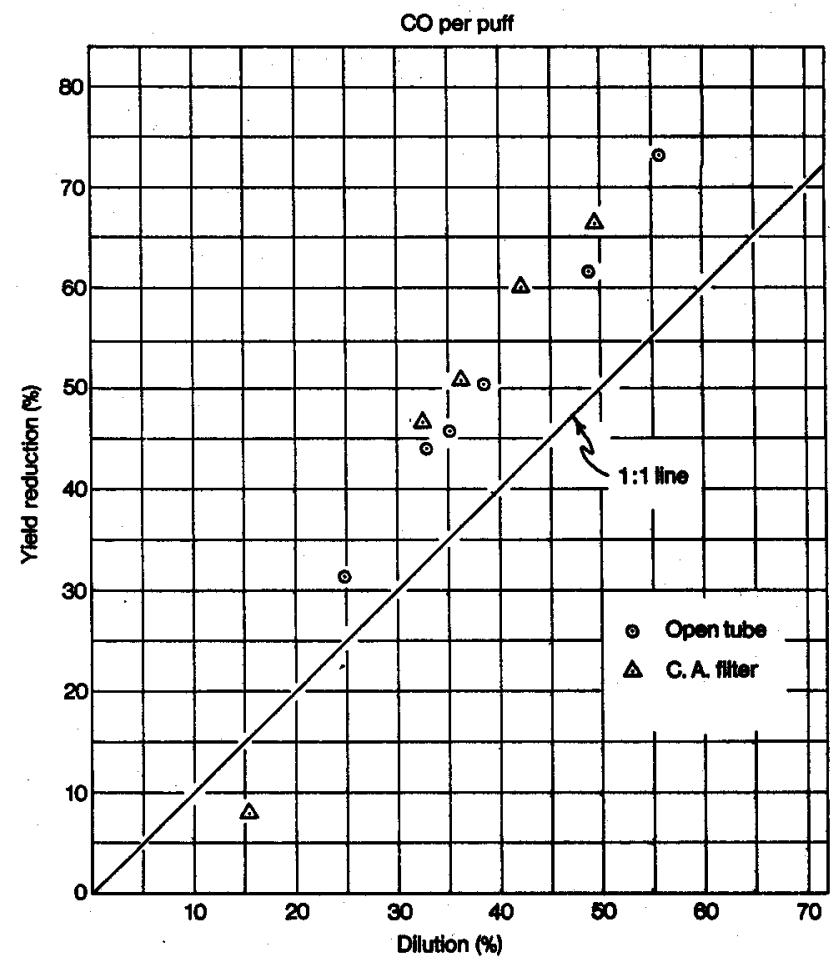


Figure 7. Hydrogen cyanide.

HCN per putf

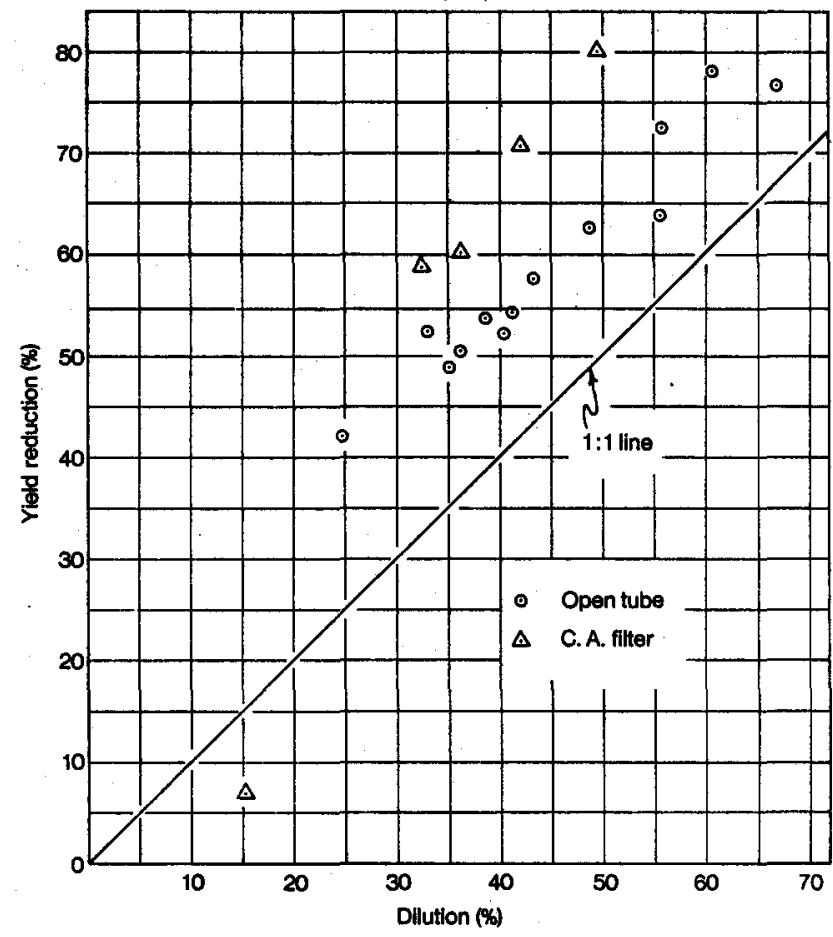

tobacco and are sublimed or distilled into smoke, a part are probably thermal degradation products of longer chain materials.

When ventilating air is introduced through tipping perforations, the principal effect is that less air is pulled past the burning cone during the puff and the cone configuration is altered. The less air is pulled past the cone the more compressed the thermal profile of the cone becomes approaching that of the freeburn configuration. It appears to be principally this

Flgure 8. Total aldehydes.

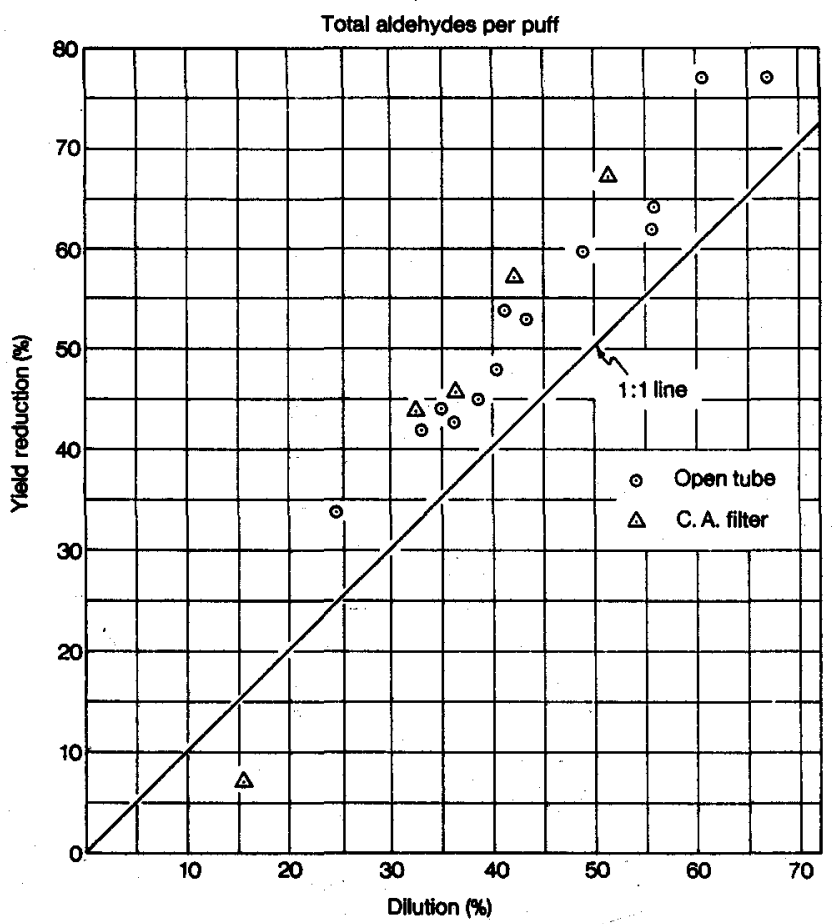

Figure 9. Particulate water.

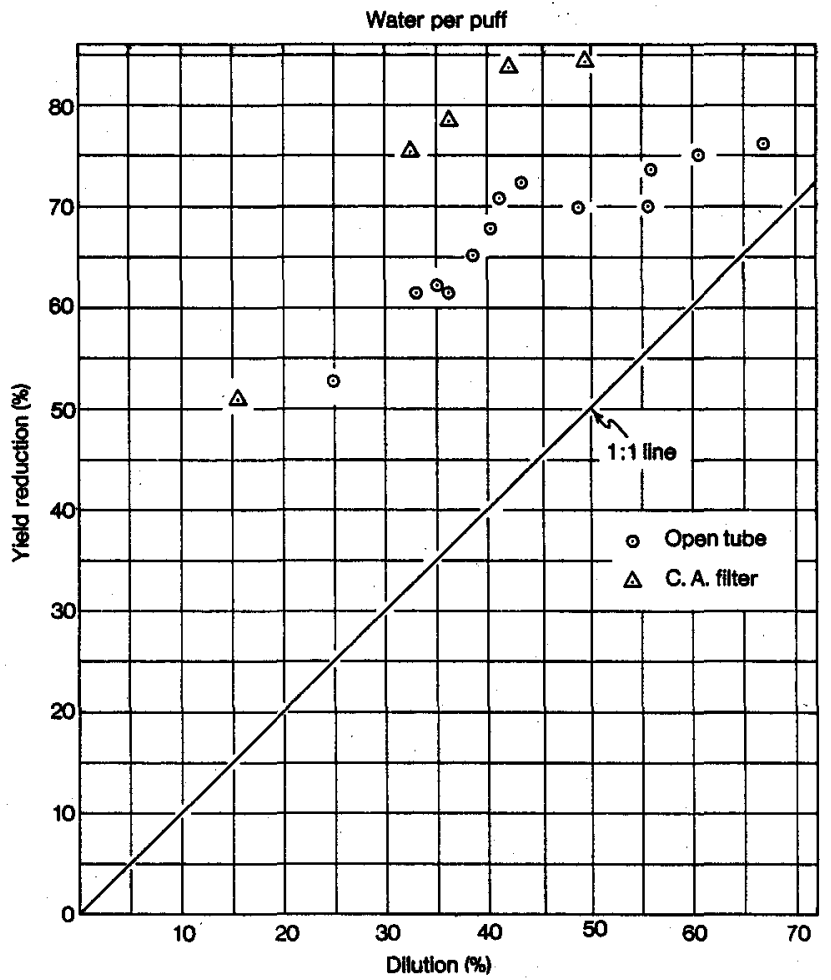

altering of the thermal profile of the cone that is responsible for the differing effect on the yields of various smoke components.

Figures 6 to 13 show some plots of experimental data depicting the degree of yield reduction achieved by various amounts of dilution.

Figure 6 shows the relationship for $C O$. The data are on the yield per puff basis. The appearance of the plot would be changed somewhat on the per cigarette basis since ventilated cigarettes give more puffs but it would still be similar.

Also plotted on the graph is a $I: I$ line expected from dilution. The control was the same cigarette without perforations.

Thus, the amount of reduction of $\mathrm{CO}$ is much larger than expected from dilution. This observation was also made by Morie and Sloan (13), Mikami, Naito and Kaburaki (12), Kiefer (5), and Roper (16). It makes no difference whether the cigarette is equipped with an open tube or a cellulose acetate filter.

Figure 7 shows the results for $\mathrm{HCN}$. The data are for total HCN, i.e., the sum of gas phase and particulate phase yields (1). Again, the degree of reduction is much greater than expected from dilution. In this case the cellulose acetate filter has a significant filtration efficiency for $\mathrm{HCN}$ which is enhanced in a yentilated cigarette.

Figure 8 depicts the data for aldehydes. The aldehydes were determined by a colorimetric procedure for Total Aldehydes (2). The data points are still above the I:I line, but much less than for $\mathrm{CO}$ or $\mathrm{HCN}$. The presence of the filter makes relatively little difference.

Figure 9 shows the results for water. This is the highest amount of reduction observed among all the 
Flgure 10. Nicotine.

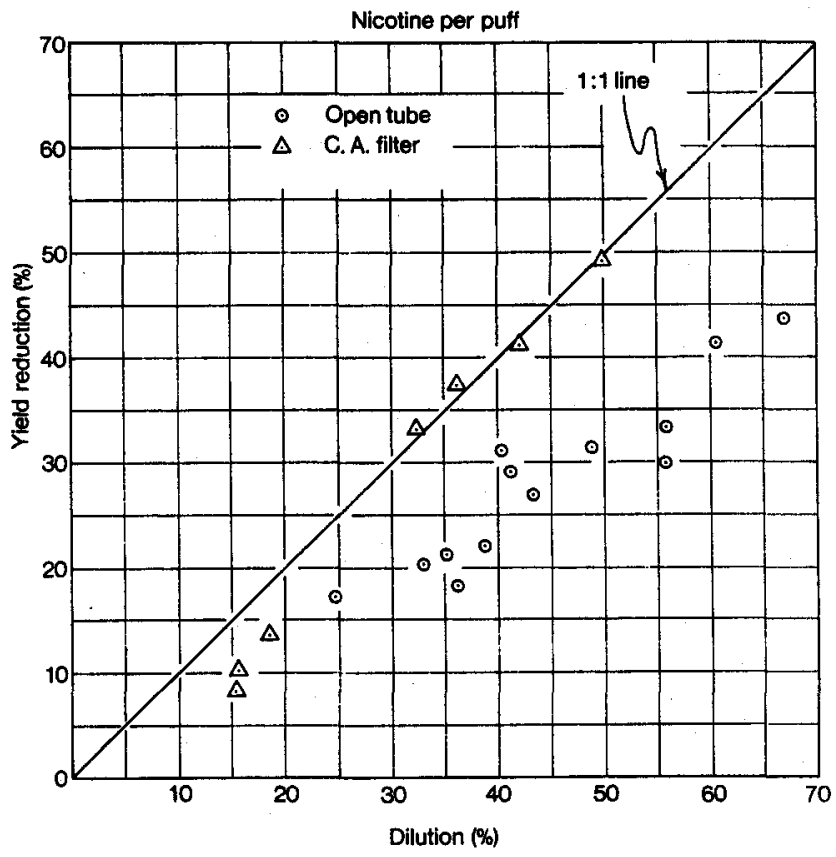

compounds examined. Part of this, however, might be an analytical artifact. Water in smoke was determined by the Cambridge filter method and it is possible that the diluting air stream which is drier than smoke might reevaporate some of the water off the Cambridge filter pad.

Figure no depicts nicotine reductions which are much below predicted values. The introduction of the filter enhances the reduction of nicotine yield significantly.

Phenols, shown in Figure 11, behave much like nicotine in the open tube configuration. The phenol data are based on a colorimetric Total Volatile Phenol analysis $(8,15)$.

With the cellulose acetate filter in place, however,

Figure 11. Volatile phenols.

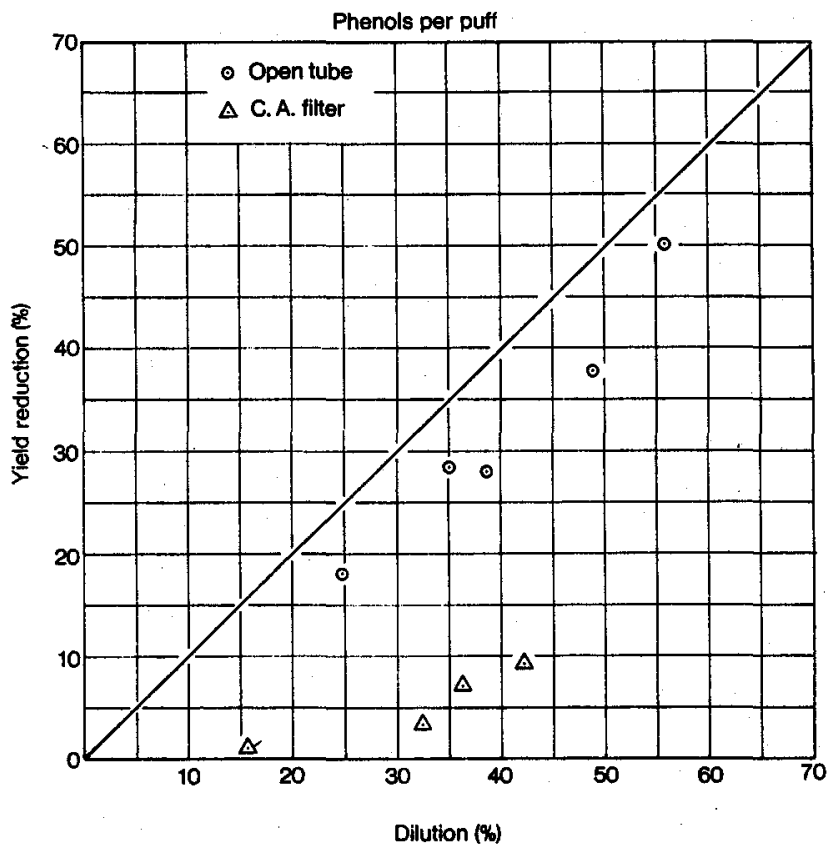

Figure 12. Wet smoke sollds.

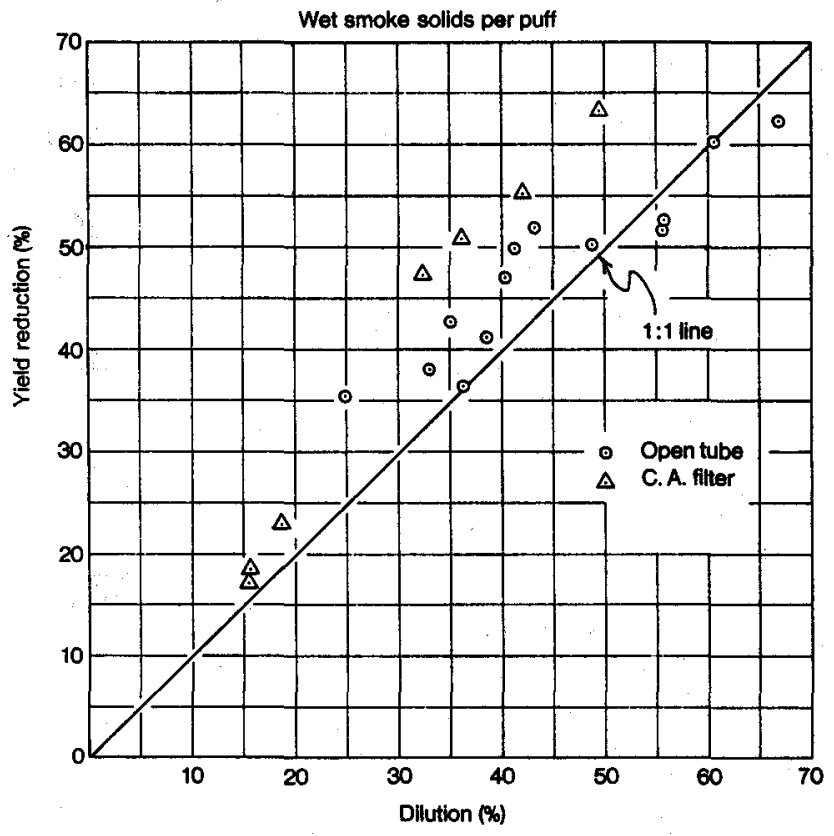

only a minimal phenol reduction was observed. Plasticized cellulose acetate has a very high filtration efficiency for phenols and apparently this efficiency is impaired by the introduction of diluting air.

Wet Smoke Solids in Figure 12 approaches the $I: 1$ line, but is above it due to the water contribution. Again, the filter shows a significantly increased efficiency.

Figure 13 shows the results. for NFDS which constitutes the bulk of particulate smoke and approaches the I. : . line most closely.

Generally, the relationships, over the dilution range examined, approach a linear correlation fairly closely. Regression equations were calculated for all the components (for open tube only) and the correlation

Figure 13. Nicotine-free-dry-smoke.

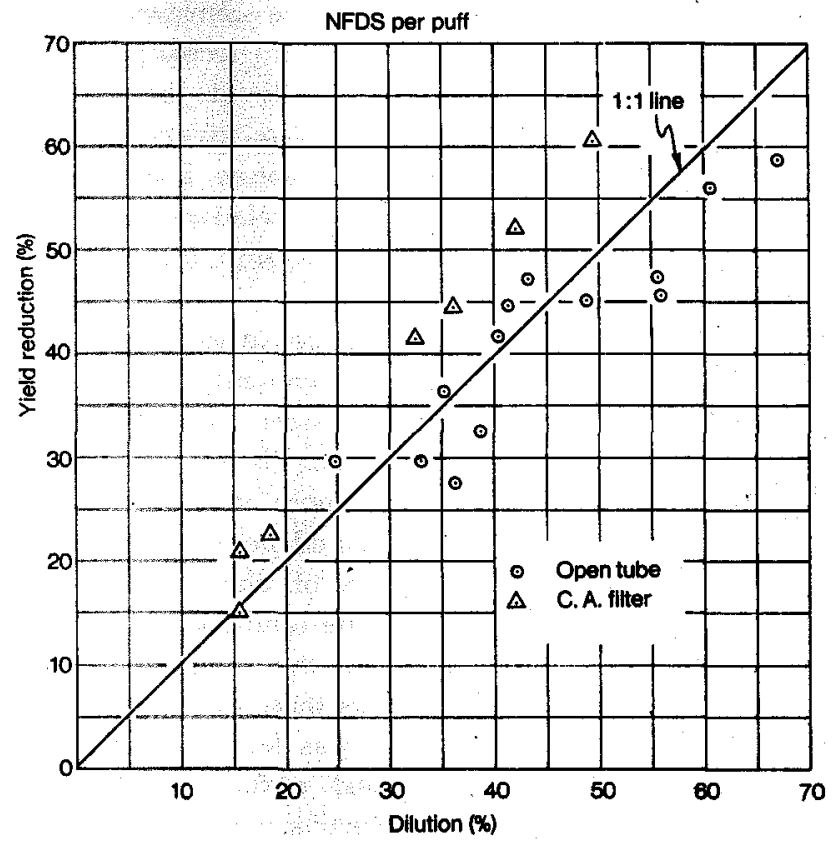


Flgure 14. Regreasion llnes for all the investigated smoke components.

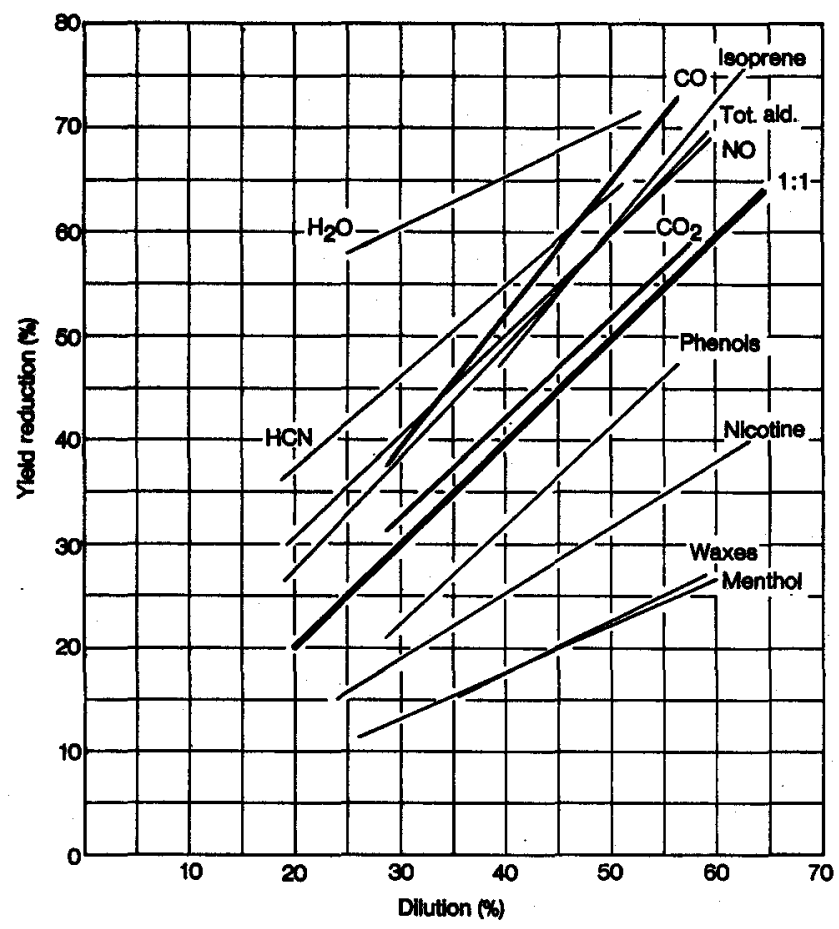

coefficients ranged from 0.90 to 0.99 . At lower degrees of dilution the relationships, of course, would become non-linear and go to 0 at $0 \%$ of dilution.

Figure 14 shows a plot of the regression lines including some smoke components for which detailed experimental data plots were not shown.

Generally, substances that are on tobacco and distil into smoke appear to have flatter slopes as a function of dilution.

All the relatively high-boiling materials - phenols, nicotine, waxes and menthol - regardless whether they are pyrolysis products or reside in tobacco as such are much less affected by ventilation then volatile degradation products. Apparently, the transport mechanism from the cone into main stream smoke becomes more efficient as the thermal profile of the cone is compressed, i. e., diluted smoke is relatively enriched in substances such as phenols and nicotine. Even though less particulate smoke is produced relatively more of these materials is able to condense onto the available smoke droplets.

It is difficult to explain the differences in yield reduction between the particulate phase components in terms of volatility. Of the two pure materials, menthol has a higher vapor pressure than nicotine (b. p. $215^{\circ} \mathrm{C}$ and $247^{\circ} \mathrm{C}$ respectively), i. e., the more volatile material is affected less by dilution as would be expected.

Phenols are made up principally of phenol, the three cresols, catechol and hydroquinone (and lesser amounts of many others), but generally the individual components have lower boiling points than nicotine. Nevertheless, the reduction observed was less than that for nicotine. Possibly, the chemical nature of phenols causes them to have a lower effective vapor pressure.
The "wax" fraction is very complicated and probably ranges from rather volatile materials to compounds of the type of dotriacontane which have a very low vapor pressure. The position of the "wax" regression line implies that the more volatile components predominate in the fraction.

The $\mathrm{CO}-\mathrm{CO}_{2}$ relationship is interesting. When less air is pulled past the cone, the $\mathrm{CO}$ yield is reduced much more drastically than that of $\mathrm{CO}_{2}$. This implies that the oxygen flow past the cone is utilized more efficiently as the volume flow rate of air decreases. $\mathrm{CO}_{2}$ yield behaves very much like what would be expected from dilution and unlike the other gaseous decomposition products. $\mathrm{CO}$ and $\mathrm{CO}_{2}$ having the same precursors, the two yields should be somewhat interdependent.

There appears to be a significant difference between $\mathrm{HCN}$, on one hand, and aldehydes, NO and isoprene on the other hand. All four have more or less specific precursors and the production of all four is affected more by a compressed thermal profile than, e. g., that of NFDS. Apparently, the time-at-temperature relationship of the different precursors in the environment of the cone is important and in particular the conversion of proteinic materials to $\mathrm{HCN}$ is impaired when the cone is shortened and is much favored in an elongated cone. The production of isoprene, aldehydes and NO even though the precursors are different appears to be affected similarly.

It is known from other studies that the proportion of water in smoke is drastically affected by changing the puff volume (in non-ventilated cigarettes) with large puffs yielding a disproportionately high amount of water in smoke. Discounting the importance of the artifact mentioned above, the large effect of compressing the thermal profile of the cone on water yield is evident here.

\section{SUMMARY}

An investigation is described concerning the effect of tipping perforations on the yield of a variety of smoke components. The degree of ventilation covered the $20-70 \%$ range.

Tipping ventilation reduces the amount of air drawn past the cone during the puff and thereby compresses the thermal profile of the cone. The yield of gaseous smoke components which have unique precursors is a function of time-at-temperature conditions in and near the cone and the effect on the yield differs between precursors as the amount of air flow is varied.

Compounds that depend on distillation or sublimation to get into main stream smoke are much less affected by tipping ventilation, i. e., condensation of these materials onto smoke particles becomes more efficient. as the air flow past the cone is reduced and less particulate smoke is produced. 
Es wurde untersucht, wie die Perforation des Filterumhüllungspapiers (bei Ventilationsgraden zwischen 20 und $70 \%$ ) auf die Ausbeute an verschiedenen Rauchbestandteilen wirkt.

Die Filterventilation verringert die Luftmenge, die während des Zuges am Glutkegel vorbei eingesaugt wird, und senkt dadurch das thermische Profil des Glutkegels. Die Ausbeute an gasförmigen Rauchbestandteilen mit jeweils spezifischen Vorläufern ist abhängig von den Zeit/ Temperatur-Verhältnissen im Glutkegel und in dessen Umgebung. Die Wirkung auf die Ausbeute differiert zwischen den Verbindungsvorstufen in dem Maße, in dem das Volumen des Luftstromes verändert wird.

Verbindungen, deren Ubergang in den Hauptstromrauch von Destillations- oder Sublimationsprozessen abhängig ist, werden viel weniger durch die filterventilation beeinflußt, d. h. die Kondensation dieser Stoffe auf Rauchpartikeln nimmt zu, wenn der Luftstrom am Glutkegel vorbei vermindert ist und weniger Partikelphase erzeugt wird.

\section{RESUME}

On décrit un travail de recherche concernant l'influence de perforations dans le papier d'enveloppement du boutfiltre sur le rendement en différents composants de fumée. Le degré de ventilation s'étend de 20 à $70 \%$.

La ventilation du bout-filtre réduit la quantité de courant d'air derrière le cône de combustion pendant la bouffée, et réduit de ce fait le profil thermique du cône. La production des composants gazeux de la fumée qui ont des précurseurs uniques est fonction du temps à température dans et près du cône, et l'influence sur la production dépend des différents précurseurs, selon que l'on varie le courant d'air.

Les composants, dont la pénétration dans le flux principal de fumée est basée sur une distillation ou une sublimation, sont moins influencés par la ventilation du bout-filtre, c.a.d. la condensation de ces composants aux particules de fumée gagne en efficience, si le courant d'air derrière le cône diminue, ce qui donne moins de fumée particulaire.

\section{REFERENCES}

1. Collins, P. F., N. M. Sarji and J. F. Williams: An automated method for determination of hydrogen cyanide in cigarette smoke; Tobacco Sci. 13 (1969) 12-15.

2. Collins, P. F., N. M. Sarji and J. F. Williams: An automated method for the determination of total aldehydes in gas phase of cigarette smoke; Tobacco Sci. 24 (1970) 182-186.

3. Imasu, T.: Dilution of gas components of cigarette smoke by diffusion and by air inflow through cigarette paper, I. Capillary paper; Jap. Monop. Corp. Cent. Res. Inst. Sci. Pap. 113 (1971) 131-137.
4. Imasu, T.: Dilution of gas components of cigarette smoke by diffusion and by air inflow through cigarette paper, II. Perforated paper; Jap. Monop. Corp. Cent. Res. Inst. Sci. Pap. 113 (1971) 139-142.

5. Kiefer, J. E.: Private communication, Tennessee Eastman Co.

6. Lipp, G., and H. van Nooy: Neue Methoden zur Messung der Porosität von Cigarettenpapier und des Ventilationsgrades von Cigaretten; Beitr. Tabakforsch. 1 (1962) 369-384.

7. Lipp, G.: Zum Problem vergleichender Untersuchungen an porösen und perforierten Cigarettenpapieren; Beitr. Tabakforsch. 3 (1966) 477-483.

8. Lorentzen, G., und G. Neurath: Quantitative Bestimmung von Phenolen in Tabakrauch mit 4-Aminoantipyrin (AAP); Beitr. Tabakforsch. 2 (1963) 73-78.

9. Meyer-Abich, K. M.: Die Strömungsverhältnisse in Cigaretten; Beitr. Tabakforsh. 3 (1966) 307-329.

10. Meyer-Abich, K. M., U. Dölberg and G. Lipp: Zur Berechnung der Korrekturfaktoren für die Messung des Ventilationsgrades; Beitr. Tabakforsch. 3 (1966) 330-338.

11. Meyer-Abich, K. M.: Die Verteilung des Ventilationsstromes auf einer Cigarette; Beitr. Tabakforsch. 3 (1966) 505-5x6.

12. Mikami, Y., N. Naito and Y. Kaburaki: Effects of some factors on carbon monoxide concentration in main stream smoke of a cigarette; Jap. Monop. Corp. Centr. Res. Inst. Sci. Pap. 113 (1971), 99-195.

13. Morie, G. P., and C. H. Sloan: The use of cryogenic temperature gas chromatography for the determination of carbon monoxide and carbon dioxide in cigarette smoke; Beitr. Tabakforsh. 6 (1972) $178-18 x$.

14. Müller, K. H., G. Neurath und H. Horstmann: Einfluß der Luftdurchlässigkeit von Cigarettenpapier auf die Ausbeute und Zusammensetzung des Rauches; Beitr. Tabakforsh. 2 (1964) 271-181.

75. Oakley, E. T., J. O. Millham and L. Weissbecker: An empirical correlation of two methods for phenols in cigarette smoke; Anal. Chim. Acta. 31 (1964) 272-278.

16. Roper, P. W.: Ventilation and its effect on cigarette properties; Paper presented at the meeting of the CORESTA Smoke Study Group held in Nice, France, September 13-14, 1973.

17. Schur, M. O., and J. C. Ridkards: The design of low yield cigarettes; Tobacco Sci. 4 (1960) 69-77.

18. Waltz, P., and M. Häusermann: Betrachtungen über die Veränderung des Tabakrauches in der Cigarette; Beitr. Tabakforsch. 3 (x965) 169-202.

The author's address:

Liggett and Myers Inc, Research Department, Durham, N.C., 27702, USA. 